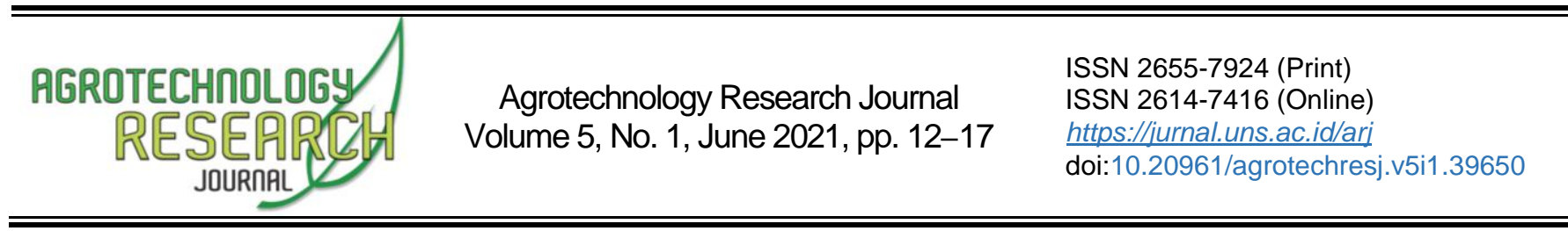

\title{
Respons Hasil beberapa Varietas Kedelai terhadap Aplikasi Pupuk Fosfat
}

\section{Response of Yield from Several Varieties of Soybean to Phosphate Fertilizer Application}

\author{
St. Subaedah ${ }^{1 *}$, Netty $^{2}$, Andi Ralle ${ }^{3}$ \\ ${ }^{1-3}$ Department of Agrotechnology, Faculty of Agriculture, Universitas Muslim Indonesia, Makassar, Sulawesi Selatan 90231 Indonesia
}

Received 02 February 2020; Accepted 05 January 2021; Published 30 June 2021

\begin{abstract}
Soybean is including a major protein source with a relatively higher consumption rate. Similarly, various efforts have been adopted towards boosting production, including selecting high-yield species and soil fertility improvement using fertilizers. This research aims to increase soybean production by employing the appropriate variety and phosphate fertilizers to improve soil fertility. This experiment was conducted in Takalar, South Sulawesi, between April-July 2019. The split-plot design method was applied with three replications. Consequently, the main plot encompasses the treatment of three varieties, termed Argomulyo, Anjasmoro and Gema, while the subplots relate to phosphate fertilization, comprising three levels, including fertilization with a dose of SP-36 at 50, 100 and $150 \mathrm{~kg}^{- \text {ha }^{-1} \text {. The results }}$ showed that the modifications in variety and phosphorus fertilization significantly influenced soybean production, as Argomulyo obtained the maximum rate of 2.77 t.ha $^{-1}$, followed by Anjasmoro at 2.45 t.ha-1 . Furthermore, phosphate fertilization with a dose of SP-36 at 100-150 kg.ha-1 demonstrated the optimal soybean production as indicated by the maximum productive nodes and pods. Therefore, no interaction was observed between the various species and phosphate fertilization.
\end{abstract}

Keywords: Crop Production; Glycine max; Phosphorus Levels; Soil Fertility

Cite this as (CSE Style): Subaedah S, Netty, Ralle A. 2021. Respons hasil beberapa varietas kedelai terhadap pemberian pupuk fosfat. Agrotechnology Res J. 5(1): 12-17. https://dx.doi.org/10.20961/agrotechresj.v5i1.39650.

\section{PENDAHULUAN}

Kebutuhan kedelai pada tahun 2018 mencapai 2,5 juta ton, sementara produksi kedelai hanya mencapai 82,598 ton (BALITKABI 2018). Oleh karena itu, pemerintah terus berupaya untuk meningkatkan produksi kedelai baik melalui program intensifikasi maupun ekstensifikasi di lahan kering, lahan sawah maupun di lahan pasang surut (Fatah dan Satna 2012). Usaha ekstensifikasi merupakan hal yang makin sulit dilakukan mengingat persaingan akan penggunaan lahan semakin besar, sehingga alternatif peningkatan produksi melalui intensifikasi relatif lebih tepat (Subaedah 2018).

Peningkatan produksi melalui usaha intensifikasi dapat dilakukan dengan perbaikan teknik budidaya, seperti pemupukan yang tepat, waktu tanam yang tepat, pengaturan pola tanam, serta penggunaan varietas unggul (Harjadi 2018). Pemilihan varietas merupakan salah satu faktor penting yang harus diperhatikan dalam melakukan usaha tani. Hal ini disebabkan, untuk mencapai produktivitas yang tinggi, sangat tergantung

${ }^{*}$ Corresponding Author:

E-Mail: st.subaedah@umi.ac.id pada potensi genetik dari varietas tersebut. Varietas unggul memiliki kelebihan dibandingkan dengan varietas lokal, seperti karakter pertumbuhan dan tingkat produksi (Sumarno 1983). Oleh karena itu penggunaan varietas unggul merupakan cara yang paling efektif dan paling efisien dalam meningkatkan produksi tanaman. Berbagai varietas unggul telah dihasilkan oleh BALITKABI, diantaranya varietas Anjasmoro, Argomulyo, Gema. Varietas Gema disukai petani karena berumur pendek, sementara varietas Argomulyo dan Anjasmoro merupakan varietas yang berbiji besar (Susanto dan Nugrahaeni 2017).

Pengelolaan lingkungan tumbuh juga merupakan faktor yang harus diperhatikan, karena kemampuan dari varietas unggul tersebut untuk menghasilkan produksi tinggi tidak akan tercapai jika lingkungan tidak menunjang (Adisarwanto 2005). Pengelolaan lingkungan tumbuh termasuk di dalamnya perbaikan ketersediaan hara melalui pemupukan. Salah satu unsur hara makro yang dibutuhkan tanaman dalam jumlah banyak dan sering bermasalah dalam ketersediaannya adalah unsur fosfor (Matsumoto 2000; Syers et al. 2008; Bolo et al. 2021).

Fosfor merupakan salah satu penyusun ATP dalam tanaman. ATP merupakan sumber energi utama untuk menggerakkan aktivitas metabolisme tanaman termasuk 
penyerapan unsur-unsur makro yang diperlukan bagi tanaman, dengan demikian ketersediaan $\mathrm{P}$ juga dapat meningkatkan ketersediaan N (Gardner et al. 2010; Roobroeck et al. 2021). Tanaman legum, termasuk kedelai membutuhkan $P$ untuk pertumbuhan yang memadai dan fiksasi $\mathrm{N}$ dan efektivitasnya dalam perbaikan tanah dapat terhalang oleh defisiensi P (Giller dan Cadisch 1995). Selanjutnya Wang et al. (2018) dan Singh dan Reddy (2016) melaporkan bahwa laju fotosintesis dan konsentrasi protein daun lebih tinggi dengan peningkatan dosis fosfor $P$ yang diberikan. Respons tanaman terhadap pemupukan $\mathrm{P}$ ditentukan oleh keadaan lingkungan dan juga varietas yang digunakan (Sandeep et al. 2008; Kurniawan et al. 2014). Hasil penelitian Taliman et al. (2019) menunjukkan adanya perbedaan respons dari varietas kedelai terhadap pupuk $P$ yang diberikan.

Penelitian ini menggunakan pupuk SP-36 sebagai sumber pupuk fosfat, karena kandungan fosfornya yang cukup tinggi $\pm 36 \%$, mudah larut dalam air dan meningkatkan pertumbuhan akar (Mabapa et al. 2010; Amrullah et al. 2016). Respons tanaman kedelai terhadap dosis fosfor bervariasi (Barbagelata et al. 2002; Burkitbayev et al. 2021). Selanjutnya dikemukakan oleh Shahid et al. (2009) bahwa aplikasi $\mathrm{P}_{2} \mathrm{O}_{5}$ dengan dosis 100 kg.ha ${ }^{-1}$ diperoleh indeks panen dan hasil kedelai yang tertinggi, sementara Subaedah, Ralle, Sabahannur (2019) menemukan aplikasi $\mathrm{P}_{2} \mathrm{O}_{5}$ dengan dosis 100-150 kg.ha-1 diperoleh hasil kedelai tertinggi. Oleh karena itu untuk meningkatkan efisiensi pemupukan $\mathrm{P}$ perlu diperhatikan kesesuaian antara kondisi lahan dan kebutuhan setiap varietas tanaman. Berdasarkan hal tersebut, maka dilakukan penelitian untuk mengkaji varietas kedelai dan dosis pupuk fosfat yang mampu meningkatkan hasil tanaman kedelai.

\section{BAHAN DAN METODE}

Penelitian ini dilaksanakan di desa Campagaya, Kecamatan Galesong, Kabupaten Takalar, Provinsi Sulawesi Selatan dengan jenis tanah Latosol, yang dilakukan dari bulan April-Juli 2019. Bahan yang digunakan adalah benih kedelai varietas Argomulyo, Anjasmoro, Gema, pupuk urea, $\mathrm{KCl}$ dan SP-36.

Penelitian ini disusun dalam bentuk Rancangan Petak Terbagi yang terdiri dari petak Utama dan anak petak. Sebagai petak utama adalah pengaruh varietas yang terdiri dari tiga taraf varietas yaitu: V1 (Argomulyo), V2 (Gema), V3 (Anjasmoro). Sementara perlakuan pemupukan fosfor sebagai anak petak yang terdiri dari tiga taraf dosis SP-36 yaitu: P1 (50 kg.ha-1), P2 (100 kg .ha-1), P3 (150 kg.ha-1). Kombinasi kedua faktor diperoleh sembilan perlakuan. Setiap kombinasi perlakuan diulang tiga kali sehingga diperoleh 27 satuan perlakuan. Data hasil pengamatan dianalisis varians dan dilanjutkan dengan uji Beda Nyata Terkecil (BNT) dengan taraf kepercayaan 0,05.

Pelaksanaan penelitian dimulai dengan membagi lahan dalam tiga blok. Setiap blok dibagi menjadi tiga petak utama yang berukuran $6 \mathrm{~m} \times 3 \mathrm{~m}$. Kemudian petak utama dibagi menjadi tiga anak petak yang berukuran $2 \mathrm{~m} \times 3 \mathrm{~m}$. Jarak antar blok dan jarak antara petak utama $100 \mathrm{~cm}$.
Penanaman benih kedelai dengan jarak tanam $40 \mathrm{~cm}$ $x 20 \mathrm{~cm}$ secara tugal. Pemupukan urea dengan dosis 100 kg.ha-1 diberikan dua kali yaitu pada $1 / 2$ dosis pada saat tanam berumur 1 minggu dan $1 / 2$ dosis pada umur 30 hari setelah tanam. Pemupukan KCL dengan dosis $100 \mathrm{~kg}$ per hektar dilakukan pada saat tanaman berumur satu minggu setelah tanam, sementara pemupukan SP36 dilakukan pada saat tanaman berumur satu minggu dengan dosis sesuai ketentuan perlakuan. Penyiangan atau pemberantasan gulma dilakukan secara manual pada umur 20 dan 40 hari setelah penanaman. Adapun parameter yang diamati dalam penelitian ini meliputi: jumlah buku produktif, jumlah polong per tanaman, bobot polong per tanaman, bobot biji per petak, bobot 100 biji dan produksi biji kering per ha. Data hasil pengamatan dianalisis sesuai dengan rancangan Petak Terbagi, dan perlakuan yang berpengaruh signifikan dilanjutkan dengan uji lanjutan BNT taraf 0,05.

\section{HASIL DAN PEMBAHASAN \\ Jumlah buku produktif}

Hasil analisis data menunjukkan bahwa perlakuan varietas dan pupuk fosfor berpengaruh nyata terhadap jumlah buku produktif (buku yang mengandung polong), tetapi interaksi antara keduanya tidak berpengaruh nyata. Hasil uji BNT taraf 0,05 menunjukkan bahwa ratarata jumlah buku produktif terbanyak diperoleh varietas Argomulyo dan Gema yaitu masing-masing 18,11 dan 18,00 buku dan berbeda nyata dengan jumlah buku produktif yang dihasilkan oleh varietas Anjasmoro (Tabel 1). Perbedaan jumlah buku dari varietas yang berbeda disebabkan karena karakter setiap varietas ditentukan oleh faktor internal tanaman (genetik) dari varietas tersebut. Perbedaan sifat genetik tersebut menyebabkan perbedaan penampilan fenotipe tanaman. Hal ini sejalan dengan hasil penelitian Siregar (2009) yang menunjukkan bahwa perbedaan varietas menampilkan perbedaan tinggi tanaman dan jumlah buku antara satu varietas dengan varietas lainya. Perbedaan ini disebabkan oleh perbedaan genetik, yang menyebabkan perbedaan penampilan fenotipik tanaman dengan menampilkan ciri dan sifat yang khusus yang berbeda antara satu sama lain dengan pengaruh lingkungan.

Perlakuan dosis pupuk fosfor menunjukkan bahwa pemupukan SP-36 dengan dosis $150 \mathrm{~kg} \cdot \mathrm{h}^{-1}$ diperoleh jumlah buku produktif yang lebih banyak yaitu 18,56 dan berbeda nyata dengan jumlah buku produktif yang diperoleh pada pemupukan SP-36 dengan dosis 50 kg.ha ${ }^{-1}$ (Tabel1). Fosfor merupakan unsur hara makro yang dibutuhkan tanaman dalam jumlah banyak untuk mendukung pertumbuhan yang maksimal, sehingga dengan peningkatan dosis maka akan menghasilkan jumlah buku produktif yang lebih banyak pula. Hal ini sejalan dengan temuan Mandic et al. (2015) yang melaporkan bahwa penanaman kedelai varietas Balkan di Serbia dengan penambahan unsur hara N, P dan $\mathrm{K}$ serta unsur mikro seperti $\mathrm{B}, \mathrm{Fe}, \mathrm{Cu}, \mathrm{Mn}$, Mo dan $\mathrm{Zn}$ meningkatkan tinggi tanaman, jumlah buku, jumlah polong, jumlah biji dan hasil biji. Demikian juga hasil penelitian Taliman et al. (2019) menunjukkan bahwa hasil kedelai tertinggi diperoleh pada aplikasi pupuk fosfor dengan dosis $150 \mathrm{~kg} \cdot \mathrm{ha}^{-1}$. 
Tabel 1. Jumlah buku produktif (buku) kedelai pada berbagai varietas dan pemupukan fosfat

\begin{tabular}{lcccl}
\hline \multirow{2}{*}{ Varietas } & \multicolumn{3}{c}{$\begin{array}{c}\text { Pemupukan Fosfat } \\
\text { (kg.ha-1) }\end{array}$} & $\begin{array}{l}\text { Rata- } \\
\text { rata }\end{array}$ \\
\cline { 2 - 4 } & 50 & 100 & 150 & \\
\hline Argomulyo & 16,67 & 18,00 & 19,67 & $18,11 \mathrm{a}$ \\
Gema & 17,00 & 18,00 & 19,00 & $18,00 \mathrm{a}$ \\
Anjasmoro & 15,00 & 15,67 & 17,00 & $15,89 \mathrm{~b}$ \\
\hline Rata-rata & $16,22 \mathrm{~b}$ & $17,22 \mathrm{ab}$ & $18,56 \mathrm{a}$ \\
\hline
\end{tabular}

Keterangan: angka yang diikuti oleh huruf yang tidak sama pada baris dan kolom rata-rata yang sama berbeda nyata berdasarkan uji BNT taraf 0,05

\section{Jumlah polong}

Hasil analisis jumlah polong menunjukkan bahwa perlakuan berbagai varietas dan pemupukan fosfat berpengaruh signifikan terhadap jumlah polong kedelai yang diperoleh (Tabel 2). Varietas Argomulyo dan Anjasmoro menghasilkan jumlah polong yang terbanyak yaitu antara $66,33-69,22$ polong dan berbeda nyata dengan varietas Gema yang hanya menghasilkan 42,78 polong. Hasil yang diperoleh sejalan dengan hasil penelitian Walid dan Susylowati (2016) yang melaporkan bahwa varietas kedelai Agromulyo memiliki jumlah polong paling tinggi ( 37,8 polong) sementara Burangran menghasilkan 25,46 polong. Demikian juga hasil penelitian Marliah et al. (2012) menemukan bahwa varietas Anjasmoro memperlihatkan produksi tertinggi yang diperlihatkan oleh jumlah polong terbanyak (145,44 polong) dan produksi biji per tanaman yang lebih tinggi dibandingkan dengan varietas lainnya.

Perlakuan pemupukan fosfat menunjukkan bahwa pemupukan fosfat SP-36 dengan dosis $100-150 \mathrm{~kg}^{-\mathrm{ha}^{-1}}$ dihasilkan jumlah polong terbanyak yaitu antara 65,8968,44 dan berbeda nyata dengan jumlah polong yang dihasilkan dari pemupukan SP-36 50 kg.ha-1 yaitu 44,00 polong. Pengaruh pemupukan fosfat terhadap jumlah polong kedelai berbanding lurus dengan jumlah buku yang diperoleh, yaitu peningkatan dosis pupuk fosfat akan meningkatkan jumlah buku dan jumlah polong tanaman kedelai. Cabang per buku pada tanaman kedelai berhubungan erat dengan jumlah polong yang diperoleh, karena posisi polong kedelai berada di buku tanaman atau ketiak daun (Adie dan Krisnawati 2013).

Tabel 2. Jumlah polong kedelai (polong) per tanaman pada beberapa varietas dan pemupukan fosfat

\begin{tabular}{|c|c|c|c|c|}
\hline \multirow{2}{*}{ Varietas } & \multicolumn{3}{|c|}{$\begin{array}{l}\text { Pemupukan Fosfat } \\
\left(\mathrm{kg} \cdot \mathrm{ha}^{-1}\right)\end{array}$} & \multirow{2}{*}{ Rata-rata } \\
\hline & 50 & 100 & 150 & \\
\hline Argomulyo & 55,00 & 84,00 & 68,67 & $69,22 \mathrm{a}$ \\
\hline Gema & 36,00 & 43,00 & 49,33 & $42,78 \mathrm{~b}$ \\
\hline Anjasmoro & 41,00 & 70,67 & 87,33 & 66,33 a \\
\hline Rata-rata & $44,00 \mathrm{~b}$ & $65,89 a$ & $68,44 a$ & \\
\hline
\end{tabular}

Keterangan: angka yang diikuti oleh huruf yang tidak sama pada baris dan kolom rata-rata yang sama berbeda nyata berdasarkan uji BNT taraf 0,05
Hasil penelitian ini sesuai dengan temuan yang diperoleh Subaedah, Ralle, Sabahannur (2019) yang menyimpulkan bahwa pemupukan fosfat sebanyak 100 $\mathrm{kg} \mathrm{ha}^{-1}$ menghasilkan jumlah polong tertinggi yaitu 75,47 polong. Demikian pula hasil penelitian Mokoena (2013) menunjukkan bahwa ketersediaan unsur hara fosfor mempengaruhi pertumbuhan dan produksi serta kualitas biji kedelai yang dihasilkan. Ketersediaan hara fosfor sangat membantu pertumbuhan dan meningkatkan produksi kedelai, karena unsur hara fosfor merupakan salah satu unsur hara esensial yang sangat diperlukan bagi tanaman kedelai, baik untuk pembentukan dan aktivitas nodul akar maupun untuk pertumbuhan dan produksi tanaman. Kebutuhan fosfor pada fase pembungaan akan meningkat tajam karena kebutuhan energi akan meningkat dan fosfor adalah komponen penyusun enzim dan ATP yang berguna dalam proses transfer energi (Gardner et al. 2010). Selanjutnya Bohner (2017) mengemukakan bahwa, fosfor dibutuhkan untuk perkembangan akar, pembentukan bunga, buah dan pengisian biji.

\section{Bobot polong per tanaman}

Data hasil analisis bobot polong kedelai per tanaman menunjukkan bahwa perlakuan berbagai varietas berpengaruh nyata terhadap bobot polong kedelai yang dihasilkan. Hasil uji lanjutan BNT taraf 0,05 pada Tabel 3 menunjukkan bahwa rata-rata bobot polong tertinggi terdapat varietas Argomulyo dan Anjasmoro yaitu masing-masing $26,72 \mathrm{~g}$ dan $30,09 \mathrm{~g}$ per tanaman dan berbeda nyata dengan varietas Gema yang menghasilkan polong sebanyak $12,13 \mathrm{~g}$ per tanaman. Hasil ini menunjukkan bahwa keragaan varietas berpengaruh terhadap bobot polong kedelai yang dihasilkan. Hal ini sejalan dengan hasil penelitian Subaedah et al. (2018); Maharani et al. (2018) menunjukkan bahwa setiap genotipe akan mempunyai respons yang berbeda yang diperlihatkan oleh pertumbuhan dan produksi yang berbeda. Hasil penelitian Adeyeye et al. (2017) yang meneliti respons tiga varietas kedelai (TGX 1740-2F, TGX 1842-IE, dan TGX 1448-2E) dan menemukan bahwa varietas TGX 1842-IE memiliki bobot polong yang nyata lebih tinggi $(36,2 \mathrm{~g})$ dibandingkan dengan varietas TGX $1740-2 \mathrm{~F}$ $(23,6 \mathrm{~g})$.

Tabel 3. Bobot polong kedelai (g) per tanaman pada berbagai varietas dan pemupukan fosfat

\begin{tabular}{lccrl}
\hline \multirow{2}{*}{ Varietas } & \multicolumn{3}{c}{$\begin{array}{c}\text { Pemupukan Fosfat } \\
\left(\mathrm{kg} \cdot \mathrm{ha}^{-1}\right)\end{array}$} & Rata-rata \\
\cline { 2 - 4 } & 50 & 100 & 150 & \\
\hline Argomulyo & 27,10 & 32,52 & 30,64 & $30,09 \mathrm{a}$ \\
Gema & 10,88 & 15,26 & 10,25 & $12,13 \mathrm{~b}$ \\
Anjasmoro & 21,26 & 28,19 & 30,71 & $26,72 \mathrm{a}$ \\
\hline Rata-rata & 19,75 & 25,32 & 23,87 & \\
\hline
\end{tabular}

Keterangan: angka yang diikuti oleh huruf yang tidak sama pada kolom rata-rata yang sama berbeda nyata berdasarkan uji BNT taraf 0,05 


\section{Bobot 100 biji kedelai}

Keragaan varietas memperlihatkan pengaruh yang signifikan terhadap parameter bobot 100 biji. Hasil uji BNT pada Tabel 4 menunjukkan bahwa rata-rata bobot 100 biji varietas Anjasmoro terberat yaitu 12,25 g dan berbeda nyata dengan bobot 100 biji yang dihasilkan varietas Gema $(9,78 \mathrm{~g})$ tetapi tidak berbeda nyata dengan bobot biji yang dihasilkan varietas Argomulyo $(12,06 \mathrm{~g})$. Bobot 100 biji merupakan salah satu indikator besarnya biji yang dihasilkan, dimana varietas Anjasmoro merupakan salah satu varietas kedelai yang berbiji besar. Hal ini didukung oleh hasil penelitian oleh lqbal et al. (2013) yang mengemukakan bahwa varietas Anjasmoro menghasilkan produksi per plot dan bobot 100 biji yang tertinggi dibandingkan varietas lainnya. Penelitian yang dilakukan oleh Bekele et al. (2016) juga menemukan bahwa bobot 100 biji kedelai dipengaruhi oleh varietas yang digunakan. Demikian juga penelitian yang dilakukan oleh Taliman et al. (2019) menemukan bahwa varietas $L P-F_{11}$ menghasilkan biji kedelai dengan bobot 100 biji sebesar $26 \mathrm{~g}$ dan berbeda nyata bobot biji yang dihasilkan oleh varietas Akimaro (16 g).

Tabel 4. Bobot 100 biji (g) kedelai pada beberapa varietas dan pemupukan fosfat

\begin{tabular}{lcccr}
\hline \multirow{2}{*}{ Varietas } & \multicolumn{3}{c}{$\begin{array}{c}\text { Pemupukan Fosfat } \\
\left(\mathrm{kg}^{\left.\mathrm{h} \mathrm{ha}^{-1}\right)}\right.\end{array}$} & Rata-rata \\
\cline { 2 - 4 } & 50 & 100 & 150 & \\
\hline Argomulyo & 11,79 & 11,84 & 12,55 & $12,06 \mathrm{a}$ \\
Gema & 9,35 & 10,08 & 9,90 & $9,78 \mathrm{~b}$ \\
Anjasmoro & 12,22 & 13,06 & 11,48 & $12,25 \mathrm{a}$ \\
\hline Rata-rata & 11,12 & 11,66 & 11,31 & \\
\hline Kennnn
\end{tabular}

Keterangan: angka yang diikuti oleh huruf yang tidak sama pada kolom yang sama berbeda nyata berdasarkan uji BNT taraf 0,05

\section{Bobot biji per petak}

Hasil analisis data bobot biji kedelai per petak menunjukkan bahwa perlakuan berbagai varietas kedelai berpengaruh nyata. Pada Tabel 5 terlihat bahwa bobot biji per petak tertinggi yaitu $262,39 \mathrm{~g}$ terdapat pada varietas Argomulyo dan berbeda nyata dengan bobot biji kedelai yang dihasilkan varietas Gema yaitu 164,89 g, tetapi tidak berbeda nyata dengan bobot biji yang dihasilkan varietas Anjasmoro yaitu sebanyak $253,71 \mathrm{~g}$ per petak. Hal ini sejalan dengan hasil penelitian Herawati et al. (2017); Mabapa et al. (2010); Darwesh et al. (2013) yang melaporkan bahwa perbedaan varietas kedelai memberi pengaruh yang signifikan terhadap hasil biji kedelai yang diperoleh.

Tabel 5. Bobot biji kedelai ( $\mathrm{g}$ ) per petak pada berbagai varietas dan pemupukan fosfat

\begin{tabular}{lcccc}
\hline \multirow{2}{*}{ Varietas } & \multicolumn{3}{c}{$\begin{array}{c}\text { Pemupukan Fosfat } \\
\left(\mathrm{kg}^{-1} \mathrm{ha}^{-1}\right)\end{array}$} & Rata-rata \\
\cline { 2 - 4 } & 50 & 100 & 150 & \\
\hline Argomulyo & 225,50 & 283,20 & 278,47 & $262,39 \mathrm{a}$ \\
Gema & 173,84 & 162,86 & 157,96 & $164,89 \mathrm{~b}$ \\
Anjasmoro & 229,55 & 260,39 & 271,20 & $253,71 \mathrm{a}$ \\
\hline Rata-rata & 209,63 & 235,48 & 235,88 & \\
\hline
\end{tabular}

Keterangan: angka yang diikuti oleh huruf yang tidak sama berbeda nyata berdasarkan uji BNT taraf 0,05

\section{Produksi biji per ha}

Analisis data produksi biji kering kedelai per ha dari hasil konversi per petak menunjukkan bahwa terdapat pengaruh yang nyata dari perlakuan berbagai varietas kedelai, tetapi pemupukan fosfat dan interaksinya tidak berpengaruh nyata. Pada Tabel 6 produksi biji kedelai tertinggi yaitu 2,77 t.ha $^{-1}$ terdapat pada varietas Argomulyo, kemudian varietas Anjasmoro dengan produksi yang dihasilkan sebanyak 2,45 t.ha $^{-1}$ dan berbeda nyata dengan produksi kedelai yang dihasilkan varietas Gema yaitu sebanyak 1,85 tha ${ }^{-1}$. Temuan ini sesuai dengan hasil penelitian Subaedah, Ralle, Netty (2019) di lahan sawah tadah hujan yang menunjukkan varietas Argomulyo dan Anjasmoro menghasilkan produksi yang lebih tinggi dibandingkan varietas Kaba, Gema dan Tidar. Gardner et al. (2010) mengemukakan bahwa tingkat produksi tanaman dipengaruhi oleh sifat genetik pada tanaman tersebut, dimana karakter setiap varietas ditentukan oleh faktor internal (genetik) dari varietas tersebut. Penelitian lain yang dilakukan oleh Sharma et al. (2011) yang menguji empat varietas kedelai dan menemukan bahwa varietas Bragg menghasilkan produksi yang tertinggi.

Tabel 6. Produksi biji kedelai (ton) per ha pada beberapa varietas dan pemupukan fosfat

\begin{tabular}{lcccc}
\hline \multirow{2}{*}{ Varietas } & \multicolumn{3}{c}{$\begin{array}{c}\text { Pemupukan Fosfat } \\
\left(\mathrm{kg} . h a^{-1}\right)\end{array}$} & Rata-rata \\
\cline { 2 - 4 } & 50 & 100 & 150 & \\
\hline Argomulyo & 2,32 & 3,07 & 2,93 & $2,77 \mathrm{a}$ \\
Gema & 1,84 & 1,91 & 1,81 & $1,85 \mathrm{~b}$ \\
Anjasmoro & 1,80 & 2,57 & 2,99 & $2,45 \mathrm{a}$ \\
\hline Rata-rata & 1,99 & 2,52 & 2,58 & \\
\hline
\end{tabular}

Keterangan: angka yang diikuti oleh huruf yang tidak sama pada kolom yang sama berbeda nyata berdasarkan uji BNT taraf 0,05

\section{KESIMPULAN}

Tidak terjadi interaksi antara varietas dan pemupukan fosfor terhadap produksi kedelai. Tanaman kedelai varietas Argomulyo dan Anjasmoro menghasilkan produksi yang lebih tinggi yaitu antara $2,45-2,77$ t.ha- $^{-1}$. Pemupukan fosfor SP-36 dengan dosis $100-150 \mathrm{~kg}^{-\mathrm{ha}^{-1}}$ menghasilkan jumlah buku produktif dan jumlah polong kedelai yang lebih banyak

\section{UCAPAN TERIMA KASIH}

Terima kasih disampaikan kepada KEMENRISTEK DIKTI yang telah memberikan bantuan biaya melalui Skim Penelitian Unggulan Perguruan Tinggi TA. 2019 dari KEMENRISTEK DIKTI dengan Kontrak No. 115/SP2H/LT/DRPM/2019.

\section{DAFTAR PUSTAKA}

Adeyeye AS, Togun AO, Olaniyan AB, Akanbi WB. 2017. Effect of fertilizer and rhizobium inoculation on growth and yield of soyabean variety (Glycine max L. Merrill). Adv Crop Sci Technol. 5(1):1-9. https://dx.doi.org/10.4172/2329-8863.1000255.

Adie MM, Krisnawati A. 2013. Biologi Tanaman Kedelai. In: Sumarno, Suyamto, Widjono A, Hermanto, Kasim $\mathrm{H}$, editors. Kedelai: Teknik Produksi dan 
Pengembangan. Malang (ID): Pusat Penelitian dan Pengembangan Tanaman Pangan, Badan Penelitian dan Pengembangan Pertanian. p. 45-73.

Adisarwanto T. 2005. Kedelai: budidaya dengan pemupukan yang efektif dan pengoptimalan peran bintil akar. Jakarta (ID): Penebar Swadaya. 107 p.

Amrullah NK, Ginting C, Setyawati ER. 2016. Pengaruh berbagai jenis dan dosis pupuk fosfat terhadap pertumbuhan bibit kelapa sawit di pre nursery. $J$ Agromast. 1(2):1-9.

BALITKABI. 2018. Dukung swasembada kedelai 2018, lewat VUB kedelai. Jakarta (ID): rilis.id. https://rilis.id/dukung-swasembada-kedelai-2018lewat-vub-kedelai.

Barbagelata P, Melchiori R, Paparotti O. 2002. Phosphorus fertilization of soybeans in clay soils of Entre Ríos province. Better Crop Int. 16(1):3-5.

Bekele W, Belete K, Tana T. 2016. Effect of soybean varieties and nitrogen fertilizer rates on yield, yield components and productivity of associated crops under maize/soybean intercropping at Mechara, Eastern Ethiopia. Agric For Fish. 5(1):1-7. https://dx.doi.org/10.11648/j.aff.20160501.11.

Bohner H. 2017. Phosphorus: an essential nutrient for soybean production. Ontario (Canada): Ministry of Agriculture, Food and Rural Affairs; [diakses 3 Januari 2020]. http://www.omafra.gov.on.ca/english/crops/field/news/cropt alk/2017/ct-0917a1.htm.

Bolo P, Kihara J, Mucheru-Muna M, Njeru EM, Kinyua M, Sommer R. 2021. Application of residue, inorganic fertilizer and lime affect phosphorus solubilizing microorganisms and microbial biomass under different tillage and cropping systems in a Ferralsol. Geoderma. 390:114962. https://doi.org/10.1016/j.geoderma.2021.114962.

Burkitbayev M, Bachilova N, Kurmanbayeva $M$, Tolenova K, Yerezhepova N, Zhumagul M, Mamurova A, Turysbek B, Demeu G. 2021. Effect of sulfur-containing agrochemicals on growth, yield, and protein content of soybeans (Glycine max (L.) Merr). Saudi J Biol Sci. 28(1):891-900. https://doi.org/10.1016/j.sjbs.2020.11.033.

Darwesh DA, Maulood PM, Amin SA. 2013. Effect of phosphorus fertilizers on growth and physiological phosphorus use efficiency of three soy bean cultivars. IOSR J Agric Vet Sci. 3(6):32-36.

Fatah A, Satna A. 2012. Teknologi budidaya kedelai pada lahan sawah. Makassar (ID): BPTP Sulawesi Selatan; [diperbaharui 19 Juli 2013; diakses 28 Desember 2019].

http://old.sulsel.litbang.pertanian.go.id/ind/index.php ?option=com_content \&view=article\&id=812:teknolog i-budidaya-kedelai-pada-lahan-sawah-tahun-terbit2012\&catid=47: panduanpetunjuk-teknis-brosur\&ltemid=231.

Gardner FP, Pearce RB, Mitchell RL. 2010. Physiology of crop plants. Jodhpur (IN): Scientific Publishers. 327 p.
Giller KE, Cadisch G. 1995. Future benefits from biological nitrogen fixation: An ecological approach to agriculture. In: Ladha JK, Peoples MD, editors. Management of biological nitrogen fixation for the development of more productive and sustainable agricultural systems. Dordrecht (NL):Kluwer Academic Publishers. p. 255-277.

Harjadi SS. 2018. Dasar-dasar agronomi. Jakarta (ID): PT Gramedia Pustaka Utama. 300 p.

Herawati N, Hipi A, Aisah AR, Tantawizal. 2018. Keragaan pertumbuhan dan hasil beberapa varietas kedelai pada berbagai pupuk organik cair di lahan kering beriklim kering. In: Pratiwi $H$, Sulistyo $A$, Lestari SAD, Sari KP, Kristiono A, Rahajeng W, editors. Inovasi Teknologi Akabi Siap Mendukung Tercapainya Swasembada dan Kedaulatan Pangan. Prosiding Seminar Nasional Hasil Penelitian Tanaman Aneka Kacang dan Umbi; 26 Juli 2017; Malang (ID). Bogor (ID): Pusat Penelitian dan Pengembangan Tanaman Pangan. p. 165-174.

lqbal M, Mawarni L, Charloq C. 2013. Pertumbuhan dan produksi beberapa varietas kedelai (Glycine max L. Merrill) pada berbagai tingkat penaungan tahap kedua. J Agroekoteknologi Univ Sumatera Utara. 1(3):896-907.

Kurniawan S, Rasyad A, Wardati W. 2014. Pengaruh pemberian pupuk posfor terhadap pertumbuhan beberapa varietas kedelai (Glycine max (L.) Merril). J Online Mhs Fak Pertan Univ Riau. 1(2):1-11.

Mabapa PM, Ogola JBO, Odhiambo JJO, Whitbread A, Hargreaves J. 2010. Effect of phosphorus fertilizer rates on growth and yield of three soybean (Glycine max) cultivars in Limpopo Province. African J Agric Res. 5(19):2653-2660.

Maharani PD, Yunus A, Harjoko D. 2018. Jarak tanam berbeda pada uji daya hasil lima varietas jagung hibrida. Agrotechnology Res J. 2(2):52-57. https://dx.doi.org/10.20961/agrotechresj.v2i2.21804.

Mandic V, Simic A, Krnjaja V, Bijelic Z, Tomic Z, Stanojkovic A, Ruzic-Muslic D. 2015. Effect of foliar fertilization on soybean grain yield. Biotechnol Anim Husb. 31(1):133-143. https://dx.doi.org/10.2298/BAH1501133M.

Marliah A, Hidayat T, Husna N. 2012. Pengaruh varietas dan jarak tanam terhadap pertumbuhan kedelai (Glycine max (L.) Merrill). J Agrista. 16(1):22-28.

Matsumoto H. 2000. Cell biology of aluminum toxicity and tolerance in higher plants. Int Rev Cytol. 200:146. https://doi.org/10.1016/S0074-7696(00)00001-2.

Mokoena TZ. 2013. The effect of direct phosphorus and potassium fertilization on soybean (Glycine max L.) yield and quality [disertasi]. Pretoria (Afrika Selatan): University of Pretoria; [diakses 16 Desember 2019]. http://hdl.handle.net/2263/40352.

Roobroeck D, Palm CA, Nziguheba G, Weil R, Vanlauwe B. 2021. Assessing and understanding nonresponsiveness of maize and soybean to fertilizer applications in African smallholder farms. Agric Ecosyst Environ. 305:107165. https://doi.org/10.1016/j.agee.2020.107165. 
Sandeep AR, Joseph S, Jisha MS. 2008. Yield and nutrient uptake of soybean (Glycine max (L) Merr) as influenced by phosphate solubilizing microorganisms. World J Agric Sci. 4(S):835-838.

Shahid MQ, Saleem MF, Khan HZ, Anjum SA. 2009. Performance of soybean (Glycine max L.) under different phosphorus levels and inoculation. Pakistan J Agric Sci. 46(4):237-241.

Sharma UC, Datta M, Sharma V. 2011. Effect of applied phosphorus on the yield and nutrient uptake by soybean cultivars on acidic hill soil. Open J Soil Sci. 1(2):45-48. https://dx.doi.org/10.4236/ojss.2011.12006.

Singh SK, Reddy VR. 2016. Methods of mesophyll conductance estimation: its impact on key biochemical parameters and photosynthetic limitations in phosphorus-stressed soybean across CO 2. Physiol Plant. 157(2):234-254. https://dx.doi.org/10.1111/ppl.12415.

Siregar AJ. 2009. Tanggap beberapa varietas kedelai (Glycine max (L.) Merrill) pada tingkat pemberian pupuk organik cair [skripsi]. Medan (Indonesia): Program Studi Pemulian Tanaman, Departemen Budidaya Pertanian, Fakultas Pertanian, Universitas Sumatera Utara.

Subaedah S. 2018. Agroteknologi lahan kering. Makassar (ID): Nas Media Pustaka. 202 p.

Subaedah S, Numba S, Saida. 2018. Penampilan pertumbuhan dan hasil beberapa genotipe jagung calon hibrida umur genjah di lahan kering . J Agron Indones. 46(2):169-174. https://dx.doi.org/10.24831/jai.v46i2.16400.

Subaedah S, Ralle A, Netty. 2019. Pertumbuhan dan produksi berbagai varietas tanaman kedelai di lahan sawah tadah hujan. J Ecosyst. 19(3):276-281.
Subaedah S, Ralle A, Sabahannur S. 2019. Phosphate fertilization efficiency improvement with the use of organic fertilizer and its effect on soybean plants in dry land. Pakistan J Biol Sci. 22(1):28-33. https://dx.doi.org/10.3923/PJBS.2019.28.33.

Sumarno DH. 1983. Kedelai dan cara bercocok tanamnya. Bogor (ID): Pusat Penerbitan dan Pengembangan Tanaman Pangan. $53 \mathrm{p}$.

Susanto GWA, Nugrahaeni N. 2017. Pengenalan dan karakteristik varietas unggul kedelai. In: Nugrahaeni $\mathrm{N}$, Taufiq A, Utomo JK, editors. Bunga rampai teknik produksi benih kedelai. Jakarta (ID): IAARD Press, Badan Penelitian dan Pengembangan Pertanian. p. 17-28.

Syers JK, Johnston AE, Curtin D. 2008. Efficiency of soil and fertilizer phosphorus: reconciling changing concepts of soil phosphorus chemistry with agronomic information. Rome (IT): Food and Agriculture Organization of the United Nations (FAO). 108 p.

Taliman NA, Dong Q, Echigo K, Raboy V, Saneoka H. 2019. Effect of phosphorus fertilization on the growth, photosynthesis, nitrogen fixation, mineral accumulation, seed yield, and seed quality of a soybean low-phytate line. Plants. 8(5):119. https://dx.doi.org/10.3390/plants8050119.

Walid LF, Susylowati S. 2016. Pengaruh konsentrasi Pupuk Organik Cair (POC) terhadap pertumbuhan dan hasil beberapa varietas tanaman kedelai (Glycine max (L.) Merill). Ziraa'ah Maj IIm Pertan. 41(1):84-96.

Wang J, Chen Y, Wang P, Li YS, Wang G, Liu P, Khan A. 2018. Leaf gas exchange, phosphorus uptake, growth and yield responses of cotton cultivars to different phosphorus rates. Photosynthetica. 56(4):1414-1421. https://dx.doi.org/10.1007/s11099-018-0845-1. 